\title{
Alkyl-Resorcinol Derivatives as Inhibitors of GDP-Mannose Pyrophosphorylase with Antileishmanial Activities
}

\author{
Hélène Levaique ${ }^{1}$, Olivier Pamlard ${ }^{1}$, Cécile Apel ${ }^{1}{ }^{\circledR}$, Jérôme Bignon ${ }^{1}{ }^{\circledR}$, Margaux Arriola ${ }^{2}$, Robin Kuhner ${ }^{2}$, \\ Khalijah Awang ${ }^{3}$, Philippe M. Loiseau ${ }^{2}$, Marc Litaudon ${ }^{1}$ (D) and Sébastien Pomel ${ }^{2, *(D)}$ \\ 1 CNRS, Institut de Chimie des Substances Naturelles, Université Paris-Saclay, UPR 2301, 91198 Gif-sur-Yvette, \\ France; helene.levaique@cnrs.fr (H.L.); olivier.pamlard@cnrs.fr (O.P.); cecile.apel@cnrs.fr (C.A.); \\ jerome.bignon@cnrs.fr (J.B.); marc.litaudon@cnrs.fr (M.L.) \\ 2 CNRS, BioCIS, Université Paris-Saclay, 92290 Châtenay-Malabry, France; margaux.arriola@hotmail.fr (M.A.); \\ robin.kuhner@gmail.com (R.K.); philippe.loiseau@universite-paris-saclay.fr (P.M.L.) \\ 3 Department of Chemistry, Faculty of Science, University of Malaya, 50603 Kuala Lumpur, Malaysia; \\ khalijah@um.edu.my \\ * Correspondence: sebastien.pomel@universite-paris-saclay.fr
}

Citation: Levaique, H.; Pamlard, O.; Apel, C.; Bignon, J.; Arriola, M.; Kuhner, R.; Awang, K.; Loiseau, P.M.; Litaudon, M.; Pomel, S.

Alkyl-Resorcinol Derivatives as Inhibitors of GDP-Mannose

Pyrophosphorylase with Antileishmanial Activities. Molecules 2021, 26, 1551. https://doi.org/ $10.3390 /$ molecules 26061551

Academic Editor:

Susana Santos Braga

Received: 10 February 2021

Accepted: 9 March 2021

Published: 11 March 2021

Publisher's Note: MDPI stays neutra with regard to jurisdictional claims in published maps and institutional affiliations.

Copyright: (C) 2021 by the authors Licensee MDPI, Basel, Switzerland. This article is an open access article distributed under the terms and conditions of the Creative Commons Attribution (CC BY) license (https:// creativecommons.org/licenses/by/ $4.0 /)$

\begin{abstract}
Leishmaniasis is a vector-borne disease caused by the protozoan parasite Leishmania found in tropical and sub-tropical areas, affecting 12 million people around the world. Only few treatments are available against this disease and all of them present issues of toxicity and/or resistance. In this context, the development of new antileishmanial drugs specifically directed against a therapeutic target appears to be a promising strategy. The GDP-Mannose Pyrophosphorylase (GDP-MP) has been previously shown to be an attractive therapeutic target in Leishmania. In this study, a chemical library of 5000 compounds was screened on both L. infantum (LiGDP-MP) and human ( $h$ GDP-MP) GDP-MPs. From this screening, oncostemonol D was found to be active on both GDP-MPs at the micromolar level. Ten alkyl-resorcinol derivatives, of which oncostemonols $E$ and $\mathrm{J}$ ( 2 and $\mathbf{3}$ ) were described for the first time from nature, were then evaluated on both enzymes as well as on L. infantum axenic and intramacrophage amastigotes. From this evaluation, compounds $\mathbf{1}$ and $\mathbf{3}$ inhibited both GDP-MPs at the micromolar level, and compound 9 displayed a three-times lower $\mathrm{IC}_{50}$ on $L i G D P-M P$, at $11 \mu \mathrm{M}$, than on $h$ GDP-MP. As they displayed mild activities on the parasite, these compounds need to be further pharmacomodulated in order to improve their affinity and specificity to the target as well as their antileishmanial activity.
\end{abstract}

Keywords: Leishmania; therapeutic target; GDP-Mannose pyrophosphorylase; natural products; alkyl-resorcinol

\section{Introduction}

Leishmaniases are a complex of neglected tropical diseases caused by the protozoan parasite from the genus Leishmania sp. and transmitted by an insect vector, the phlebotomine sandfly. Three main forms of clinical manifestations can be observed in leishmaniases depending on the Leishmania species considered: (i) the cutaneous form causing skin sores, which are often self-healing, provoked by L. major in North Africa or L. mexicana in South America for example, (ii) the muco-cutaneous form, which is highly disfiguring and is caused by L. braziliensis in South America, and (iii) the visceral form, which is lethal without treatment and is caused by L. infantum in the Mediterranean Basin or L. donovani in East Africa or in India for example [1]. Currently, more than 1 billion people are threatened by this parasitic disease worldwide, with 30,000 and 1 million new cases of visceral and cutaneous leishmaniasis, respectively [2]. During its life cycle, the parasite is characterized by two forms: a mobile flagellated and elongated promastigote form in the sandfly and a round, aflagellated and intracellular amastigote form in mammal hosts [3]. Only few treatments, including antimoniates, miltefosine, paromomycin and liposomal 
amphotericin B, are currently available against leishmaniases and present several issues of toxicity, emergence of resistance, and cost. The development of new antileishmanial agents is a priority in order to circumvent these treatment limitations. In particular, the identification of new compounds specifically directed against a therapeutic target in the parasite could be a promising approach.

The surface of Leishmania is composed of many mannose-containing glycoconjugates, such as lipophosphoglycans, proteophosphoglycans, glycosylinositolphospholipids, or glycosylphosphatidylinositol, which are essential for host cell recognition [4,5]. The mannosylation pathway requires the conversion of mannose into a nucleotide sugar, GDP-mannose, which is further used as a substrate by mannosyltransferases to transfer mannose on growing glycoconjugates. In this pathway, the formation of GDP-mannose is catalyzed by the GDP-Mannose Pyrophosphorylase (GDP-MP) from the substrates mannose-1-phosphate and GTP [6]. A knockout in L. mexicana demonstrated that GDP-MP is essential for amastigote survival both in vitro and in vivo [7,8]. Moreover, from molecular modelling studies, several differences have been evidenced in the catalytic site of leishmanial GDP-MP compared to the human counterpart, allowing the development of inhibitors specifically directed against the leishmanial enzyme [9,10]. Therefore, GDP-MP constitutes an interesting therapeutic target for the development of new specific antileishmanial agents. Indeed, two independent studies identified GDP-MP inhibitors with in vitro antileishmanial activities: one from a high-throughput screening of a library of small molecules with $\mathrm{IC}_{50}$ at the submicromolar range on the enzyme and at $21.9 \mu \mathrm{M}$ on the parasite (compond-100) [11], and one from the screening of 100 compounds rationally designed from GDP-MP molecular models with a $\mathrm{K}_{i}$ at $7 \mu \mathrm{M}$ on the enzyme and an $\mathrm{IC}_{50}$ at the submicromolar level on the parasite (compound-99) [12].

In order to increase the diversity of leishmanial GDP-MP inhibitors, we screened a library of 5000 natural products on both recombinant leishmanial (LiGDP-MP from L. infantum) and human ( $h$ GDP-MP) in the present study. These leishmanial GDP-MP inhibitors were further analyzed for their in vitro antileishmanial activity.

\section{Results and Discussion}

Following a screening of an in-house library of 5000 natural compounds on both leishmanial and human GDP-MP, oncostemonol D (1), which had been isolated from Virotia francii in a previous phytochemical study, was found to be active on both LiGDP-MP and $h$ GDP-MP with similar $\mathrm{IC}_{50}$ at the micromolar range (Table 1 ). Moreover, the $\mathrm{IC}_{50}$ of this compound on both axenic and intramacrophage amastigotes was above $50 \mu \mathrm{M}$, with a $\mathrm{CC}_{50}$ at $34.4 \mu \mathrm{M}$, therefore giving a low selectivity index $(\mathrm{SI}<1)$. These results prompted us to evaluate the efficacy of other structurally related compounds on both enzymes, LiGDP-MP and $h$ GDP-MP, and on L. infantum amastigotes in vitro. Compounds 1-3 and 9-11 were isolated from the New Caledonian species Virotia francii (Proteaceae) and Tapeinosperma schlechteri (Primulaceae), respectively (Figure 1), while compounds 4-8 were isolated from the Malaysian species Knema hookeriana (Myristicaceae; Figure 1). Among these, only compounds 2 and 3, oncostemonol I and oncostemonol J, respectively, presented also a resorcinol cycle at one end of the alkyl chain and a resorcinol monomethyl ether at the other end, as in 1. However, unlike 1, compounds 2 and 3 either lack the unsaturation at the C8 position (2; Figure 1), or present a slighter longer alkyl chain (3; Figure 1). Similar $\mathrm{IC}_{50 \mathrm{~s}}$ were obtained on both $L i$ GDP-MP and $h$ GDP-MP, between $5.9 \mu \mathrm{M}$ and $13.7 \mu \mathrm{M}$ for compound 2 , and between $2.3 \mu \mathrm{M}$ and $1.9 \mu \mathrm{M}$ for compound 3, showing a low specificity of action of these compounds on the leishmanial target. Moreover, oncostemonol J (3) displayed a similar antileishmanial activity to oncostemonol D (1), with an $\mathrm{IC}_{50}$ above $25 \mu \mathrm{M}$ on both axenic and intramacrophage amastigotes (Table 1). 
Table 1. Evaluation of resorcinol derivatives on LiGDP-MP, $h$ GDP-MP, and on L. infantum axenic and intramacrophage amastigotes, and their cytotoxicity.

\begin{tabular}{|c|c|c|c|c|c|c|}
\hline Name & $\begin{array}{l}\mathrm{LiGDP-MP} \mathrm{IC} \mathrm{I}_{50} \\
\quad(\mu \mathrm{M}) \pm \mathrm{SD}\end{array}$ & $\begin{array}{l}h \mathrm{GDP}^{\mathrm{G} M P} \mathrm{IC}_{50} \\
\quad(\mu \mathrm{M}) \pm \mathrm{SD}\end{array}$ & $\begin{array}{c}\text { L. infantum } \\
\text { Axenic Amastigotes } \\
\mathrm{IC}_{50}(\mu \mathrm{M}) \pm \mathrm{SD}\end{array}$ & $\begin{array}{c}\text { L. infantum } \\
\text { Intramacrophage Amastigotes } \\
\mathrm{IC}_{50}(\mu \mathrm{M}) \pm \mathrm{SD}\end{array}$ & $\begin{array}{c}\text { Cytotoxicity } \\
\text { on RAW } 264.7 \\
\mathrm{CC}_{50}(\mu \mathrm{M}) \pm \mathrm{SD}\end{array}$ & $\begin{array}{l}\text { Selectivity } \\
\text { Index }\end{array}$ \\
\hline $\begin{array}{c}1 \\
\text { Oncostemonol D }\end{array}$ & $3.5 \pm 11.4$ & $1.3 \pm 0.2$ & $78.9 \pm 3.1$ & $>50$ & $34.4 \pm 1.5$ & $<0.7$ \\
\hline $\begin{array}{c}2 \\
\text { Oncostemonol I }\end{array}$ & $5.9 \pm 3.5$ & $13.7 \pm 14.2$ & ND & ND & ND & ND \\
\hline $\begin{array}{c}\text { 3 } \\
\text { Oncostemonol J }\end{array}$ & $2.3 \pm 8.1$ & $1.9 \pm 0.4$ & $49.5 \pm 4.2$ & $>25$ & $31.8 \pm 1.6$ & $<1.2$ \\
\hline$\stackrel{4}{\text { Khookerianic acid B }}$ & $120.0 \pm 27.5$ & $79.9 \pm 5.9$ & $>100$ & $>100$ & $83.1 \pm 7.0$ & $<0.8$ \\
\hline $\begin{array}{c}5 \\
\text { Anagigantic acid }\end{array}$ & $50.6 \pm 4.8$ & $38.3 \pm 4.1$ & $>100$ & $>100$ & $>100$ & / \\
\hline 6 & $100.2 \pm 16.6$ & $122.2 \pm 26.1$ & $>100$ & $42.7 \pm 1.3$ & $>100$ & $>2.3$ \\
\hline 7 & $16.9 \pm 5.0$ & $29.0 \pm 2.5$ & $>100$ & $>100$ & $>100$ & / \\
\hline 8 & $9.8 \pm 3.2$ & $13.9 \pm 0.6$ & $>100$ & $>100$ & $>100$ & / \\
\hline 9 & $11.0 \pm 4.7$ & $31.1 \pm 10.7$ & $53.3 \pm 4.6$ & $>25$ & $26.1 \pm 6.4$ & $<1$ \\
\hline 10 & $14.1 \pm 3.8$ & $21.9 \pm 6.3$ & $25.9 \pm 5.9$ & $>25$ & $17.9 \pm 1.3$ & $<0.7$ \\
\hline 11 & $>300$ & ND & $13.3 \pm 4.4$ & $9.5 \pm 2.1$ & $32.6 \pm 7.4$ & 3.4 \\
\hline Miltefosine & $>250$ & ND & $1.0 \pm 0.3$ & $6.7 \pm 1.7$ & $54.2 \pm 5.8$ & 8.1 \\
\hline
\end{tabular}

Selectivity Index = CC50/IC50 on intramacrophage amastigotes, ND = Not Determined.<smiles>COc1cc(O)cc(CCC/C=C\CCCc2cc(O)cc(O)c2)c1</smiles><smiles>[R]P[R]#P</smiles><smiles>CCCC/C=C/CCCc1cccc(O)c1C(=O)O</smiles><smiles>CCCCCCCCCCCCCCCCOP(=O)([O-])OCC[N+](C)(C)C</smiles>

Miltefosine

Figure 1. Structures of compounds 1-11.

All the other compounds from the series presented either a resorcinol or a resorcinol monomethyl ether (9-11), or a salicylic cycle derivative (4-8), at only one end of the linear aliphatic chain (Figure 1). Compounds 4-8 are therefore anacardic acids. Among the anacardic acids, compounds 7 and $\mathbf{8}$ were the most active compounds on the leishmanial GDP-MP with $\mathrm{IC}_{50}$ at $16.9 \mu \mathrm{M}$ and $9.8 \mu \mathrm{M}$, respectively (Table 1). Moreover, compound 8 displayed a similar $\mathrm{IC}_{50}$ on the human enzyme, while compound 7 was approximately two times less active on $h$ GDP-MP showing a mild specificity of action of this latter compound on LiGDP-MP. Unfortunately, none of the anacardic acids displayed an activity on axenic amastigotes showing an absence of target inhibition within the parasite, despite an interesting activity on the leishmanial purified enzyme. Nevertheless, compound 6 displayed a mild antileishmanial activity on intramacrophage parasites, with an absence of cytotoxicity, giving therefore a potential interesting SI above 2.3. As this compound does not inhibit axenic amastigotes, it would not act directly on the parasite, but it would rather inhibit parasite growth via the host cell. This host-directed mechanism of action has also been described for other compounds [13-15].

Among the other resorcinol derivatives, compounds $\mathbf{9}$ and $\mathbf{1 0}$ have an unsaturated alkyl chain which only differs in the number of carbons: 15 for compound 9 and 17 for 
compound 10 (Figure 1). These compounds displayed interesting $\mathrm{IC}_{50 \mathrm{~s}}$ of $11.0 \mu \mathrm{M}$ and $14.1 \mu \mathrm{M}$, respectively, on the leishmanial GDP-MP (Table 1). Moreover, both compounds displayed smaller activities on $h \mathrm{GDP}-\mathrm{MP}$, with $\mathrm{IC}_{50}$ at $31.1 \mu \mathrm{M}$ and $21.9 \mu \mathrm{M}$ for 9 and 10, respectively. These data show that both compounds would act with a slightly higher specificity on LiGDP-MP than on $h$ GDP-MP. However, they displayed only a mild activity on axenic amastigotes and no significant inhibition of intramacrophage parasites was observed. These results show that the length of alkyl chain in these alkyl-mono-resorcinol does not have an effect on their antileishmanial activity.

Additionally, compound $\mathbf{1 1}$ has no activity on the leishmanial target (Table 1). This compound has the same structure as $\mathbf{9}$ except that it presents a resorcinol monomethyl ether cycle instead of a resorcinol cycle (Figure 1). These results show the importance of the resorcinol group in the alkyl-mono-resorcinol compounds analyzed in the present study to inhibit $L i$ GDP-MP enzyme activity. Despite its lack of activity on the purified GDP-MP, compound-11 displayed a reasonable antileishmanial activity on both axenic and intramacrophage amastigotes with $\mathrm{IC}_{50}$ at $13.3 \mu \mathrm{M}$ and $9.5 \mu \mathrm{M}$, respectively, with a cytotoxicity at $32.6 \mu \mathrm{M}$ (Table 1). These results show that the antileishmanial activity of $\mathbf{1 1}$ is not mediated through GDP-MP inhibition in the parasite.

Interestingly, miltefosine, a reference drug used in the treatment of leishmaniasis, did not show any activity on leishmanial GDP-MP, despite antileishmanial activities at the micromolar level (Table 1). Therefore, the mechanism of action of this alkylphosphocholine, with a saturated linear $\mathrm{C}_{16}$ chain (hexadecylphosphocholine), is not mediated by the inhibition of leishmanial GDP-MP. Moreover, these results show the importance of the resorcinol group at the end of the linear aliphatic chain of compounds $\mathbf{9}$ and $\mathbf{1 0}$ to inhibit GDP-MP.

The structures of compounds 4-11 are formed with a mono- or dihydroxyphenol ring and a long linear aliphatic carbon chain, which gives these compounds an amphiphilic character [16]. They have a strong affinity for biological membranes, resulting in significant changes in the biophysical properties of the lipid bilayers. [17]. Although the membrane disrupting effect is highly dependent on the condition in which they interact in the lipid layer $[18,19]$, this property may explain at least in part their antiprotozoal, antimicrobial, and cytotoxic activity [17].

Among all the compounds evaluated, compounds 1, 3, 9, and 10 displayed an activity on the leishmanial target as well as on axenic amastigotes, but not on intramacrophage parasites. As a comparison, a 2-substituted quinoline named compound- $\mathbf{9 9}$ was previously identified to inhibit specifically the leishmanial GDP-MP LdGDP-MP with a $K_{i}$ at $7 \mu \mathrm{M}$ and to display an $\mathrm{IC}_{50}$ at the micromolar level on both axenic and intramacrophage L. donovani amastigotes, but with a cytotoxicity in the same range [12]. Furthermore, compound-100, a 4-substituted quinoline, was previously shown to display an antileishmanial activity on both axenic and intramacrophage amastigotes of L. donovani, L. mexicana, and L. major $\mathrm{IC}_{50 \mathrm{~s}}$ between $12 \mu \mathrm{M}$ and $49 \mu \mathrm{M}$, and to inhibit both $L d$ GDPMP and $h$ GDP-MP with a $\mathrm{K}_{i}$ between 20 and $62 \mu \mathrm{M}[11,12]$. This compound was also able to inhibit L. major GDP-MP with an interesting $\mathrm{IC}_{50}$ at $0.58 \mu \mathrm{M}$, which is lower than the more active compounds reported in the present work [11]. As the activity of compounds 1, 3, 9, and $\mathbf{1 0}$ is only moderate on axenic amastigotes, the synthesis of new derivatives could allow an improvement in their antileishmanial activity as well as their affinity and their specificity for the leishmanial GDPMP. In the literature, some alkylresorcinols have been shown to display an antileishmanial activity at the micromolar to submicromolar level $[20,21]$. These alkylresorcinols have 17 carbons in their alkyl chain, as does compound $\mathbf{1 0}$ in our study, with at least two unsaturations. Therefore, some derivatives of compound $\mathbf{1 0}$ with several unsaturations in the alkyl chain would be useful to be further synthesized and evaluated for their antileishmanial activity as well as their capacity to inhibit the leishmanial GDP-MP.

Moreover, the absence of activity of compounds 1, 3, 9, and 10 on intramacrophage parasites could be due to an inability of the compounds to cross the macrophage plasma membrane and/or the membrane of the parasitophorous vacuole before reaching the 
parasite. Therefore, a formulation of these compounds would increase their ability to reach the parasite in its vacuole, and thus would promote their antileishmanial activity on intramacrophage amastigotes. Among the possible formulations that could be used, a liposomal formulation may be the most relevant as the alkyl chain of the compounds could insert in liposomal lipid bilayers, and liposomes are targeted in vivo to the liver of infected animals where the parasites proliferate during visceral leishmaniasis.

\section{Materials and Methods}

\subsection{Plant Materials}

Wood of Virotia francii (Guill.) P.H.Weston \& A.R.Mast (Proteaceae) and bark of Tapeinosperma schlechteri Mez (Primulaceae) were collected in New Caledonia (Prony bay in August 2005, and "Forêt faux bon secours" in May 1998, under the reference DUM-0542 and LIT-0517, respectively). Herbarium specimens were deposited at the Herbier IRD de Nouméa.

Bark and twigs of Knema hookeriana Warb. (Myristicaceae) were collected in April 1996 in Gunung Bujang Melaka (Kampar, Perak, Malaysia). A voucher specimen (KL-4584) was deposited in the herbarium of the Department of Chemistry of the Science Faculty, University of Malaya (Kuala Lumpur, Malaysia).

\subsection{Extraction and Compounds Isolation}

Air dried wood of Virotia francii (900 g), bark and twigs of Knema hookeriana (100 g) and bark of Tapeinosperma schlechteri $(100 \mathrm{~g})$ were extracted by maceration in EtOAc $(3 \times 2 \mathrm{~L}$, $3 \times 300 \mathrm{~mL}$ and $3 \times 300 \mathrm{~mL}$, respectively), to yield $15 \mathrm{~g}(\mathrm{CE}-1), 2.5 \mathrm{~g}(\mathrm{CE}-2)$ and $0.8 \mathrm{~g}$ (CE-3) of crude extracts, respectively, after concentration in vacuo at $40^{\circ} \mathrm{C}$. The crude extract CE-1 (7.7 g) was subjected to silica gel column flash chromatography (RediSep Teledyn Isco, $120 \mathrm{~g}$ ) using a gradient of $n$-heptane- $\mathrm{CH}_{2} \mathrm{Cl}_{2}$ (50:50 to 0:100), then $\mathrm{CH}_{2} \mathrm{Cl}_{2}-\mathrm{MeOH}$ (100:0 to 80:20) to afford 17 fractions F1-F17. Fraction F14 $\left(\mathrm{CH}_{2} \mathrm{Cl}_{2}-\mathrm{MeOH} 90: 10\right)$ was subjected to a preparative HPLC (Kromasil $\mathrm{C}_{18}$ column, $250 \times 21.2 \mathrm{~mm}, 5 \mu \mathrm{m}$, at $21 \mathrm{~mL} / \mathrm{min}$ ) using an isocratic mobile phase of $\mathrm{MeCN}-\mathrm{H}_{2} \mathrm{O} 87: 13+0.1 \%$ formic acid to afford compounds 1-3 (19.6, 4.5 and $82.7 \mathrm{mg}$, respectively). The isolation of compounds $4-8$ from CE-2 is described in reference [22]. The crude extract CE-3 was subjected to a preparative HPLC using an isocratic mobile phase of $\mathrm{MeCN}-\mathrm{H}_{2} \mathrm{O} 85: 15+0.1 \%$ formic acid to afford compounds 9-11 $(39,65$, and $170 \mathrm{mg}$, respectively).

\subsection{Structural Identification of Compounds (1-11, Figure 1)}

NMR spectra were recorded with a Bruker spectrometer (Avance $300 \mathrm{MHz}$ for ${ }^{1} \mathrm{H}$ and $75 \mathrm{MHz}$ for ${ }^{13} \mathrm{C}$, Bruker, Wissembourg, France) using $\mathrm{CDCl}_{3}$ as solvent. MS data were acquired using a Waters Acquity UPLC coupled to a Waters LCT Premier XE mass spectrometer (HRMS analysis) or to a Waters Acquity TQ Detector (MS2 analysis).

From $V$. francii: Oncostemonol D, ( $\left.8^{\prime} Z\right)-1$-hydroxy-3-methoxy-5-[16'-( $3^{\prime \prime}, 5^{\prime \prime}$-dihydroxyphenyl)-8'-hexadecen-1'-yl]benzene (1) was isolated [23].

The structure of novel oncostemonols I and J ( 2 and 3 ) were elucidated on the basis of extensive 1D and 2D NMR spectroscopic interpretation. The structure of oncostemonols I (2) and J (3) were very similar to that of $\mathbf{1}$, except for the absence of the $\Delta^{8^{\prime}, 9^{\prime}}$ double bond for compound 2, and the presence of an unsaturated alkyl chain including two additional methylene groups for compound 3 . The stereochemistry at the double bond between $\mathrm{C}-10^{\prime} / \mathrm{C}-11^{\prime}$ of $\mathbf{3}$ was assigned as $\mathrm{Z}$, as in the case of oncostemonol $\mathrm{D}$, on the basis of the close similarity of coupling constants and ${ }^{13} \mathrm{C}$ NMR values [24]. The location of the double bonds on the carbon chains of compounds 1 and 3 were determined from ESIMS experiments in negative mode. In the MS spectrum of 3 , the mass fragments observed at $191,233,245$, and 287 are indicative of a pattern of peaks with a $54 \mathrm{amu}$ window, which is composed of peaks due to allylic cleavage via 1,4-elimination of $\mathrm{H}_{2}$ [25]. Combined with biogenetic consideration, it can deduced from these results that the double bond was located at C-10' [26]. 
Oncostemonol I, 1-hydroxy-3-methoxy-5-[16'-( $3^{\prime \prime}, 5^{\prime \prime}$-dihydroxyphenyl)-hexadecanyl] benzene (2). Colorless liquid, negative ESI-HR-MS, $m / z 455.3157[\mathrm{M}-\mathrm{H}]^{-}$[calcd. for $\left.\mathrm{C}_{29} \mathrm{H}_{43} \mathrm{O}_{4}, 455.3156\right] .{ }^{1} \mathrm{H}$ NMR $\left(300 \mathrm{MHz}, \mathrm{CDCl}_{3}, \delta, \mathrm{ppm}, J / \mathrm{Hz}\right): 1.29-1.58(28 \mathrm{H}), 2.50(4 \mathrm{H})$, $3.72\left(\mathrm{OCH}_{3}\right), 6.08,\left(1 \mathrm{H}, \mathrm{t}, J=2.1, \mathrm{H}-4^{\prime \prime}\right), 6.14\left(2 \mathrm{H}, \mathrm{d}, J=2.0, \mathrm{H}-2^{\prime \prime}, \mathrm{H}-6^{\prime \prime}\right), 6.17(1 \mathrm{H}, \mathrm{t}, J=$ 2.1, H-2), $6.22(2 \mathrm{H}, \mathrm{d}, 2.0 \mathrm{~Hz}, \mathrm{H}-4, \mathrm{H}-6) .{ }^{13} \mathrm{C} \mathrm{NMR}\left(75 \mathrm{MHz}, \mathrm{CDCl}_{3}, \delta, \mathrm{ppm}\right): 29.2-31.2$ $\left(\mathrm{C}-2^{\prime}-\mathrm{C}-15^{\prime}\right), 36.3\left(\mathrm{C}-1^{\prime}, \mathrm{C} 16^{\prime}\right), 55.6\left(\mathrm{OCH}_{3}\right), 99.2(\mathrm{C}-2), 100.4\left(\mathrm{C}-4^{\prime \prime}\right), 107.8\left(\mathrm{C}-2^{\prime \prime}, \mathrm{C}-6^{\prime \prime}\right), 106.2$ (C-4), 108.7 (C-6), $146.1\left(\mathrm{C}-5, \mathrm{C}-1^{\prime \prime}\right), 157.9\left(\mathrm{C}-3^{\prime \prime}, \mathrm{C}-5^{\prime \prime}\right), 158.0$ (C-1), 161.4 (C-3).

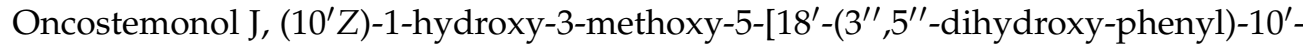
octodecen-1'-yl]benzene (3). Colorless liquid, negative ESI-HR-MS, $m / z$ 481.3333 [M - H] ${ }^{-}$ [calcd. for $\mathrm{C}_{31} \mathrm{H}_{45} \mathrm{O}_{4}, 481.3312$ ]. ${ }^{1} \mathrm{H}$ NMR $\left(300 \mathrm{MHz}, \mathrm{CDCl}_{3}, \delta, \mathrm{ppm}, \mathrm{J} / \mathrm{Hz}\right): 1.29-1.58(12 \mathrm{H}$, $\left.\mathrm{H}-2^{\prime}-\mathrm{H}-7^{\prime}, \mathrm{H}-12^{\prime}-\mathrm{H}-17^{\prime}\right), 2.01\left(2 \mathrm{H}, \mathrm{H}-8^{\prime}, \mathrm{H}-11^{\prime}\right), 2.50\left(2 \mathrm{H}, \mathrm{H}-1^{\prime}, \mathrm{H}-18^{\prime}\right), 3.75\left(\mathrm{OCH}_{3}\right), 5.34$ $\left(2 \mathrm{H}, \mathrm{t}, J=4.7 \mathrm{~Hz}, \mathrm{H}-9^{\prime}, \mathrm{H}-10^{\prime}\right), 6.17,\left(1 \mathrm{H}, \mathrm{t}, J=2.1, \mathrm{H}-4^{\prime \prime}\right), 6.23(1 \mathrm{H}, \mathrm{t}, J=2.1, \mathrm{H}-2), 6.24(2 \mathrm{H}$, $\left.\mathrm{d}, J=2.0, \mathrm{H}-2^{\prime \prime}, \mathrm{H}-6^{\prime \prime}\right), 6.27(1 \mathrm{H}, \mathrm{d}, 2.0 \mathrm{~Hz}, \mathrm{H}-6), 6.32(1 \mathrm{H}, \mathrm{d}, 2.0 \mathrm{~Hz}, \mathrm{H}-4) .{ }^{13} \mathrm{C}$ NMR $(75$ $\left.\mathrm{MHz}, \mathrm{CDCl}_{3}, \delta, \mathrm{ppm}\right): 27.3-31.2\left(\mathrm{C}-2^{\prime}-\mathrm{C}-9^{\prime}, \mathrm{C}-12^{\prime}-\mathrm{C}-17^{\prime}\right), 36.6\left(\mathrm{C}-1^{\prime}, \mathrm{C}^{\prime} 8^{\prime}\right), 55.6\left(\mathrm{OCH}_{3}\right), 98.9$ (C-2), 100.3, (C-4' $), 106.9$ (C-4), $108.0\left(\mathrm{C}-6, \mathrm{C}-2^{\prime \prime}, \mathrm{C}-6^{\prime \prime}\right), 130.1\left(\mathrm{C}-10^{\prime}, \mathrm{C}-11^{\prime}\right), 145.9\left(\mathrm{C}-1^{\prime \prime}\right)$, 146.2 (C-5), $156.7\left(\mathrm{C}-3^{\prime \prime}, \mathrm{C}-5^{\prime \prime}\right), 156.8$ (C-1), 160.8 (C-3).

From K. hookeriana: Khookerianic acid B (4), anagigantic acid (5), (Z)-2-hydroxy-6(tridec-8-en-1-yl)benzoic acid (6), 2-hydroxy-6-tridecylbenzoic acid (7), (Z)-2-hydroxy-6(pentadec-10-en-1-yl)benzoic acid (8) [22].

From T. schlechteri: ( $\left.8^{\prime} Z\right)$-5-(pentadeca-8'-enyl)benzene-1,3-diol (9) [27], ( $\left.8^{\prime} Z\right)$-5-(heptadeca$8^{\prime}$-enyl)benzene-1,3-diol (10) [27], and ( $8^{\prime} Z$ )-1-hydroxy-3-methoxy-5 (pentadeca-8'enyl)benzene (11) [28].

\subsection{GDP-MP Production and Purification}

Recombinant His6 tagged GDP-MP from L. infantum (LiGDP-MP) was produced in E. coli and purified using Ni-nitrilotriacetic acid (Ni-NTA) and size exclusion chromatography Hiload ${ }^{\mathrm{TM}} 16 / 60$ Superdex $^{\mathrm{TM}} 200$ column as previously described for $L d$ GDP-MP [12]. Recombinant His-tagged GDP-MP from human ( $h \mathrm{GDP}-\mathrm{MP}$ ) was produced in E. coli and purified using a Mono-Q anion exchange column followed by a Hiload ${ }^{\mathrm{TM}} 16 / 60$ Superdex $^{\mathrm{TM}}$ 200 column as previously described [12].

\subsection{Enzyme Assays}

GDP-MP catalyzes the following reaction:

$$
\text { Man-1-P + GTP } \rightarrow \text { GDP-Mannose + Pyrophosphate }
$$

Enzyme activities of both $L i$ GDP-MP and $h$ GDP-MP were measured at $37{ }^{\circ} \mathrm{C}$ for $20 \mathrm{~min}$ in 384 well plates in a $20-\mu \mathrm{L}$ reaction containing $50 \mathrm{mM}$ Tris- $\mathrm{HCl} \mathrm{pH} 7.5,5 \mathrm{mM}$ $\mathrm{MgCl}_{2}, 100 \mu \mathrm{M}$ Mannose-1-phosphate, $100 \mu \mathrm{M}$ GTP, $1 \mathrm{mM}$ DTT, $0.1 \mathrm{U} / \mathrm{mL}$ inorganic pyrophosphatase (Sigma-Aldrich, Saint-Quentin-Fallavier, France) and $2 \mathrm{ng} / \mu \mathrm{L}$ of recombinant GDP-MP [12,29]. The reaction was initiated by the addition of GDP-MP, and was stopped after adding $20 \mu \mathrm{L}$ of revelation buffer containing malachite green $(0.03 \% w / v)$, ammonium molybdate $(0.2 \% w / v)$ and Triton X-100 $(0.05 \% v / v)$ in $\mathrm{HCl}(0.7 \mathrm{M})$ for $5 \mathrm{~min}$ at $37^{\circ} \mathrm{C}$. The quantity of inorganic phosphate generated, representing GDP-MP activity, was determined by measuring $\mathrm{OD}_{650 \mathrm{~nm}}$ with a spectrometer plate reader Polar Omega (BMG LabTech, Champigny-sur-Marne, France). The molar extinction coefficient $\varepsilon$ of the end product detected was determined at $27,207 \mathrm{M}^{-1} \mathrm{~cm}^{-1}$ as previously described [12].

\subsection{Evaluation of Compounds on Purified Enzymes}

To evaluate compounds on purified GDP-MPs, enzyme activities were measured as described above in the presence of $100 \mu \mathrm{g} / \mathrm{mL}$ of natural products originating from a chemical library from ICSN (Institut de Chimie des Substances Naturelles, Gif-surYvette). The inhibitors were added in the reaction mix, before the addition of GDPMP. The percentage of inhibition was then calculated in reference to untreated enzyme. The statistical parameter (Z-factor) was calculated to validate the quality of the HTS 
assays as described previously [30]. As a control, compounds were evaluated in parallel in the same conditions on inorganic pyrophosphatase alone in order to discard falsepositives. No significant inhibition $(<5 \%)$ of inorganic pyrophosphatase was observed with the positive compounds selected in the present study. Furthermore, no effect was observed on the activity of both LiGDP-MP and $h$ GDP-MP with $1 \%$ DMSO, corresponding to the maximal solvent concentration used at $100 \mu \mathrm{g} / \mathrm{mL}$ of compound. Compounds presenting a minimum of $50 \%$ inhibition on a leishmanial GDP-MP were subsequently selected to determine, in a separate experiment, their $\mathrm{IC}_{50}$ by using two-fold dilutions of the compounds from $100 \mu \mathrm{g} / \mathrm{mL}$ to $3 \mathrm{ng} / \mathrm{mL}$. The $\mathrm{IC}_{50}$ were determined by nonlinear regression using GraphPad Prism 7.0 and further converted in $\mu \mathrm{M}$ in order to normalize units in Table 1. Enzyme inhibition assays were performed in triplicate in three independent experiments.

\subsection{Cell Cultures}

Promastigotes of Leishmania infantum (MHOM/FR/2008/LEM5700) were cultured in the dark at $26{ }^{\circ} \mathrm{C}$ with $5 \% \mathrm{CO}_{2}$ in M199 complete medium containing M199 medium supplemented with adenosine $(100 \mu \mathrm{M})$, hemin $(0.5 \mathrm{mg} / \mathrm{L})$, Hepes $(40 \mathrm{mM}) \mathrm{pH} 7.4$, and heat inactivated foetal bovine serum (10\%; HIFBS). Cultures of axenic amastigotes of L. infantum were adapted from [31]. Briefly, axenic amastigotes of L. infantum were obtained from late log promastigotes diluted at $1 \times 10^{6} / \mathrm{mL}$ in M199 complete medium acidified at $\mathrm{pH} 5.5$ and cultured at $37^{\circ} \mathrm{C}$ with $5 \% \mathrm{CO}_{2}$.

The RAW 264.7 macrophages (ATCC) were cultured at $37^{\circ} \mathrm{C}$ with $5 \% \mathrm{CO}_{2}$ in DMEM complete medium containing Dulbecco's Modified Eagle's Medium (DMEM, Invitrogen, Thermo-Fisher, Villebon-sur-Yvette, France) supplemented with penicillin-streptomycin (100 U/mL; Invitrogen), and heat-inactivated fetal bovine serum (10\%; HIFBS).

\subsection{In Vitro Evaluation of Compounds' Cytotoxicity}

Cytotoxicity was evaluated on RAW 264.7 macrophages. Cells were plated in 96-well microplates at a density of $2 \times 10^{4}$ cells per well. After an incubation of $24 \mathrm{~h}$ at $37^{\circ} \mathrm{C}$ with $5 \% \mathrm{CO}_{2}$, the medium was removed in each well, and $100 \mu \mathrm{L}$ of DMEM complete medium containing two-fold serial dilutions of the compounds, from $100 \mu \mathrm{M}$ to $0.049 \mu \mathrm{M}$, was added to each well. After $48 \mathrm{~h}$ of incubation at $37^{\circ} \mathrm{C}$ with $5 \% \mathrm{CO}_{2}, 10 \mu \mathrm{L}$ of resazurin $(450 \mu \mathrm{M})$ was added to each well, and further incubated in the dark for $4 \mathrm{~h}$ at $37^{\circ} \mathrm{C}$ with $5 \% \mathrm{CO}_{2}$. In living cells, resazurin is reduced in resorufin, and this conversion is monitored by measuring $\mathrm{OD}_{570 \mathrm{~nm}}$ (resorufin) and $\mathrm{OD}_{600 \mathrm{~nm}}$ (resazurin; multimode microplate reader Spark ${ }^{\circledR}$, Tecan, Lyon, France). The cytotoxicity of the compounds was expressed as $C_{50}$ (Cytotoxic Concentration 50\%: concentration inhibiting macrophage metabolic activity by $50 \%$ ) and was determined by nonlinear regression in GraphPad Prism 7.0. In vitro cytotoxicity assays were performed in triplicate in three independent experiments.

\subsection{In Vitro Antileishmanial Evaluation of Compounds on Axenic and Intramacrophage Amastigotes}

The evaluations of activity on axenic amastigotes were adapted from the protocols previously described [12]. Briefly, two-fold serial dilutions of the compounds, from $100 \mu \mathrm{M}$ to $0.049 \mu \mathrm{M}$, were performed in $100 \mu \mathrm{L}$ of complete medium (see above) in 96-well microplates. Axenic amastigotes were then added to each well at a density of $10^{6} / \mathrm{mL}$ in a $200 \mu \mathrm{L}$ final volume. After $72 \mathrm{~h}$ of incubation at $37^{\circ} \mathrm{C}$ with $5 \% \mathrm{CO}_{2}, 20 \mu \mathrm{L}$ of resazurin $(450 \mu \mathrm{M})$ was added to each well and further incubated in the dark for $24 \mathrm{~h}$ at $37^{\circ} \mathrm{C}$ with $5 \%$ $\mathrm{CO}_{2}$. Cell viability was then monitored as described above. The activity of the compounds was expressed as $\mathrm{IC}_{50}$, which was determined by nonlinear regression using GraphPad Prism 7.0. Miltefosine was used as the reference drug.

Concerning the evaluation on intramacrophage amastigotes, the determination of the cytotoxicity as presented above was necessary to use the highest drug concentrations to be studied on the intramacrophage amastigote model. RAW 264.7 macrophages were plated in 16-well Lab-Tek chamber slides (Thermo-FisherVillebon-sur-Yvette, France) at 
a density of $2 \times 10^{4}$ cells per well and incubated for $24 \mathrm{~h}$ at $37^{\circ} \mathrm{C}$ with $5 \% \mathrm{CO}_{2}$. Axenic amastigotes were differentiated as described above, centrifuged at $2000 \times g$ for $10 \mathrm{~min}$, resuspended in DMEM complete medium, and added to each well to reach a 16:1 parasite to macrophage ratio. After $24 \mathrm{~h}$ of infection at $37^{\circ} \mathrm{C}$ with $5 \% \mathrm{CO}_{2}$, extracellular parasites were removed, and DMEM complete medium $(100 \mu \mathrm{L})$ containing two-fold serial dilutions of the compounds, from $100 \mu \mathrm{M}$ to $0.049 \mu \mathrm{M}$, was added to each well. A positive control treated with $1 \%$ DMSO was added to each Lab-tek chamber-slide. After $48 \mathrm{~h}$ of treatment, the medium was removed and cells were fixed in methanol for $1 \mathrm{~min}$, stained in $10 \%$ Giemsa (Merck) for $5 \mathrm{~min}$, and further rinsed in water before observation in phase contrast at the microscope (Olympus CX31; Olympus, Rungis, France). The number of amastigotes was counted by two independent experimenters for a total of 300 macrophages per well and the ratio of amastigotes per macrophage was determined for each condition. This ratio was further compared with the one of the positive control, considered as $100 \%$, to determine a percentage of inhibition (\% I), as follows: \% I = $100-($ ratio of amastigotes per macrophage in treated cells/ratio of amastigotes per macrophages in untreated cells) $\times 100$ ). The activity of the compounds was expressed as $\mathrm{IC}_{50}$, which was determined by nonlinear regression using GraphPad Prism 7.0. Miltefosine was used as the reference drug. In vitro antileishmanial evaluations were performed in triplicate in three independent experiments.

Author Contributions: Conceptualization, P.M.L. and S.P.; Methodology H.L., O.P., C.A., M.A. and R.K.; validation, J.B., M.L. and S.P.; formal analysis, H.L., O.P., C.A., J.B., M.A., R.K., M.L. and S.P.; investigation, H.L., O.P., C.A., J.B., M.A., R.K., M.L. and S.P.; resources, C.A., K.A. and M.L.; writing original draft preparation, S.P.; writing-review editing, J.B., P.M.L., M.L. and S.P.; supervision, S.P.; funding acquisition, M.L. and S.P. All authors have read and agreed to the published version of the manuscript.

Funding: This research was funded by an "Investissement $\mathrm{d}^{\prime}$ Avenir" grant managed by Agence Nationale de la Recherche (CEBA, ANR-10-LABX-25-01).

Data Availability Statement: All data are already provided in the manuscript.

Acknowledgments: The authors are very grateful to South Province of New Caledonia, which facilitated our field investigations. The authors gratefully thank Vincent Dumontet (CNRS-ICSN) and Teo Leong Eng (UM) for the collection and identification of Virotia francii and Knema hookeriana, respectively. We are also very grateful to Erell Le Borgne (ICSN) for his help in the isolation and purification of compounds 1-3, and Nathalie Hue (ICSN) for the realization of mass spectrometry experiments. This work was carried out in the framework of the International French Malaysian Natural Product Laboratory (IFM-NatPro-Lab) established between CNRS-ICSN and the University Malaya.

Conflicts of Interest: The authors declare no conflict of interest.

Sample Availability: Samples of the compounds are available from the authors.

\section{References}

1. Roatt, B.M.; de Oliveira Cardoso, J.M.; De Brito, R.C.F.; Coura-Vital, W.; de Oliveira Aguiar-Soares, R.D.; Reis, A.B. Recent advances and new strategies on leishmaniasis treatment. Appl. Microbiol. Biotechnol. 2020, 104, 8965-8977. [CrossRef]

2. World Health Organization. Leishmaniasis Fact Sheet. 2 March 2020. Available online: https://www.who.int/news-room/factsheets/detail/leishmaniasis (accessed on 10 March 2021).

3. Batista, M.F.; Najera, C.A.; Meneghelli, I.; Bahia, D. The parasitic intracellular lifestyle of Trypanosomatids: Parasitophorous vacuole development and survival. Front. Cell. Dev. Biol. 2020, 8, 396. [CrossRef]

4. Descoteaux, A.; Turco, S.J. Glycoconjugates in Leishmania infectivity. Biochim. Biophys. Acta 1999, 1455, 341-352. [CrossRef]

5. Pomel, S.; Loiseau, P.M. GDP-mannose: A key-point for target identification and drug design in kinetoplastids. In Trypanosomatid Diseases: Molecular Routes to Drug Discoveries; Jäger, T., Koch, O., Flohe, L., Eds.; Wiley-VCH Verlag GmbH and Co. KGaA: Weinheim, Germany, 2013; Volume 4, pp. 315-334.

6. Pomel, S.; Mao, W.; Ha-Duong, T.; Cavé, C.; Loiseau, P.M. GDP-Mannose Pyrophosphorylase: A biologically validated target for drug development against leishmaniasis. Front. Cell. Infect. Dis. 2019, 9, 186. [CrossRef]

7. Garami, A.; Ilg, T. Disruption of mannose activation in Leishmania mexicana: GDP-mannose pyrophosphorylase is required for virulence, but not for viability. EMBO J. 2001, 20, 3657-3666. [CrossRef] 
8. Stewart, J.; Curtis, J.; Spurck, T.P.; Ilg, T.; Garami, A.; Baldwin, T.; Courret, N.; McFadden, G.I.; Davis, A.; Handman, E. Characterisation of a Leishmania mexicana knockout lacking guanosine diphosphate-mannose pyrophosphorylase. Int. J. Parasitol. 2005, 35, 861-873. [CrossRef]

9. Pomel, S.; Rodrigo, J.; Hendra, F.; Cavé, C.; Loiseau, P.M. In silico analysis of a therapeutic target in Leishmania infantum: The guanosine-diphospho-D-mannose pyrophosphorylase. Parasite 2012, 19, 63-70. [CrossRef]

10. Daligaux, P.; Bernadat, G.; Tran, L.; Cavé, C.; Loiseau, P.M.; Pomel, S.; Ha-Duong, T. Comparative study of structural models of Leishmania donovani and human GDP-mannose pyrophosphorylases. Eur. J. Med. Chem. 2016, 107, 109-118. [CrossRef] [PubMed]

11. Lackovic, K.; Parisot, J.P.; Sleebs, N.; Baell, J.B.; Debien, L.; Watson, K.G.; Curtis, J.M.; Handman, E.; Street, I.P.; Kedzierski, L. Inhibitors of Leishmania GDP-mannose pyrophosphorylase identified by high-throughput screening of small-molecule chemical library. Antimicrob. Agents Chemother. 2010, 54, 1712-1719. [CrossRef]

12. Mao, W.; Daligaux, P.; Lazar, N.; Ha-Duong, T.; Cavé, C.; van Tilbeurgh, H.; Loiseau, P.M.; Pomel, S. Biochemical analysis of leishmanial and human GDP-mannose pyrophosphorylases and selection of inhibitors as new leads. Sci. Rep. $2017,7,751$. [CrossRef]

13. Zahid, M.S.H.; Johnson, M.M.; Tokarski, R.J., 2nd; Satoskar, A.R.; Fuchs, J.R.; Bachelder, E.M.; Ainslie, K.M. Evaluation of synergy between host and pathogen-directed therapies against intracellular Leishmania donovani. Int. J. Parasitol. Drugs Drug Resist. 2019, 10, 125-132. [CrossRef] [PubMed]

14. De Muylder, G.; Vanhollebeke, B.; Caljon, G.; Wolfe, A.R.; McKerrow, J.; Dujardin, J.C. Naloxonazine, an amastigote-specific compound, affects Leishmania parasites through modulation of host-encoded functions. PLoS Negl. Trop. Dis. 2016, 10, e0005234. [CrossRef]

15. Gupta, N.; Noël, R.; Goudet, A.; Hinsinger, K.; Michau, A.; Pons, V.; Abdelkafi, H.; Secher, T.; Shima, A.; Shtanko, O.; et al. Inhibitors of retrograde trafficking active against ricin and Shiga toxins also protect cells from several viruses, Leishmania and Chlamydiales. Chem. Biol. Interact. 2017, 267, 96-103. [CrossRef] [PubMed]

16. Kozubek, A.; Zarnowski, R.; Stasiuk, M.; Gubernator, J. Natural amphiphilic phenols as bioactive compounds. Cell. Mol. Biol. Lett. 2001, 6, 351-355.

17. Stasiuk, M.; Kosubek, A. Biological activity of phenolic lipids. Cell. Mol. Life Sci. 2010, 67, 841-860. [CrossRef] [PubMed]

18. Siwko, M.E.; de Vries, A.H.; Mark, A.E.; Kosubek, A.; Marrink, S.J. Disturb or stabilize? A molecular dynamics study of the effects of resorcinolic lipids on phospholipid bilayers. Biophys. J. 2009, 96, 3140-3153. [CrossRef]

19. Gubernator, J.; Stasiuk, M.; Kosubek, A. Dual effect of alkylresorcinols, natural amphiphilic compounds, upon liposomal permeability. Biochim. Biophys. Acta 1999, 1418, 253-260. [CrossRef]

20. Jimenez-Romero, C.; Torres-Mendoza, D.; Urena-Gonzalez, L.D.; Ortega-Barria, E.; McPhail, K.L.; Gerwick, W.H.; Cubilla-Rios, L. Hydroxyalkenylresorcinols from Stylogyne turbacensis. J. Nat. Prod. 2007, 70, 1249-1252. [CrossRef]

21. Jin, W.; Zjawiony, J.K. 5-alkylresorcinols from Merulius incarnatus. J. Nat. Prod. 2006, 69, 704-706. [CrossRef] [PubMed]

22. Gény, C.; Rivière, G.; Bignon, J.; Birlirakis, N.; Guittet, E.; Awang, K.; Litaudon, M.; Roussi, F.; Dumontet, V. Anacardic acids from Knema hookeriana as modulators of Bcl-xL/Bak and Mcl-1/Bid interactions. J. Nat. Prod. 2016, 79, 838-844. [CrossRef]

23. Chaturvedula, V.S.; Schilling, J.K.; Miller, J.S.; Andriantsiferana, R.; Rasamison, V.E.; Kingston, D.G.I. New cytotoxic bis 5alkylresorcinol derivatives from the leaves of Oncostemon bojerianum from the Madagascar rainforest. J. Nat. Prod. 2002, 65, 1627-1632. [CrossRef]

24. Chuang, T.H.; Wu, P.L. Cytotoxic 5-alkylresorcinol metabolites from the leaves of Grevillea robusta. J. Nat. Prod. 2007, 70, 319-323. [CrossRef]

25. Suzuki, Y.; Esumi, Y.; Yamagushi, I. Structure of 5-alkylresorcinol-related analogue in rye. Phytochemistry 1999, 52, 281-289. [CrossRef]

26. Kozubek, A.; Tyman, J.H.P. Resorcinolic lipids, the natural non-isoprenoid phenolic amphiphiles and their biological activity. Chem. Rev. 1999, 99, 1-26. [CrossRef] [PubMed]

27. Madrigal, R.V.; Spencer, G.F.; Plattner, R.D.; Smith, C.R., Jr. Alkyl- and alkenylresorcinols in Rapanea laetevirens seed lipids. Lipids 1977, 12, 402-406. [CrossRef]

28. Marner, F.J.; Horper, W. Phenols and quinones from seeds of different Iris species. Helvet. Chim. Acta 1992, 75, 1557-1562. [CrossRef]

29. Davis, A.J.; Perugini, M.A.; Smith, B.J.; Stewart, J.D.; Ilg, T.; Hodder, A.N.; Handman, E. Properties of GDP-mannose pyrophosphorylase, a critical enzyme and drug target in Leishmania mexicana. J. Biol. Chem. 2004, 279, 12462-12468. [CrossRef]

30. Zhang, J.H.; Chung, T.D.Y.; Oldenburg, K.R. A simple statistical parameter for use in evaluation and validation of high throughput screening assays. J. Biomol. Screen. 1999, 4, 67-73. [CrossRef]

31. Saar, Y.; Ransford, A.; Waldman, E.; Mazareb, S.; Amin-Spector, S.; Plumblee, J.; Turco, S.J.; Zilberstein, D. Characterization of developmentally-regulated activities in axenic amastigotes of Leishmania donovani. Mol. Biochem. Parasitol. 1998, 95, 9-20. [CrossRef] 